\title{
A veleszületett maxillofacialis deformitások klinikai aspektusai
}

\author{
Sólya Kitti dr. ${ }^{1}$ - Dézsi Csilla ${ }^{2}$ - Vanya Melinda dr. ${ }^{3}$ - Szabó János dr. ${ }^{1}$ \\ Sikovanyecz János $\mathrm{dr}^{3}{ }^{3}$ - Kozinszky Zoltán dr. ${ }^{4}$ - Szili Károly dr. ${ }^{1,5}$ \\ Szegedi Tudományegyetem, Általános Orvostudományi Kar, \\ Szent-Györgyi Albert Orvos- és Gyógyszerésztudományi Centrum, ${ }^{1}$ Orvosi Genetika Intézet, \\ ${ }^{2}$ Igazságügyi Orvostani Intézet, \\ ${ }^{3}$ Szülészeti és Nőgyógyászati Klinika, Szeged \\ ${ }^{4}$ Blekinge Kórház, Szülészeti és Nógyógyászati Osztály, Svédország \\ ${ }^{5}$ Mediteam Szeged Zrt., Szeged
}

\begin{abstract}
Az ajak- és szájpadhasadék a veleszületett rendellenességek egyik leggyakoribb típusa. A szerző́k célja, hogy összefoglaló irodalmi ismereteket nyújtsanak a kórképről. A nemzetközi szakirodalom áttekintésén és megvitatásán túl kiemelik a megelőzés lehetőségeit, a genetikai és környezeti tényezők szerepét, az anatómiai és embriológiai jellemzőket, a prae- és a postnatalis diagnózis és kezelés lehetőségeit. Az etiológia multifaktoriális, mind genetikai, mind környezeti faktorok együttes hatása sokszínú fenotípusos és klinikai jellemzőkhöz vezet. A praenatalis diagnosztikában, megelőzésben, genetikai tanácsadás során és a sebészi kezelési stratégiával kapcsolatban a megfelelő multidiszciplináris ismeretek hiánya komoly diagnosztikai hibákhoz vagy tévedésekhez vezethet, ezért kiemelten fontos a klinikai csapatmunka ezekkel az állapotokkal kapcsolatban. A professzionális csapatmunka és multidiszciplináris együttmúködés garantálja az optimális ellátást és jobb életminőséget biztosít a betegek és családjuk számára. Orv. Hetil., 2015,
\end{abstract} $156(37), 1483-1490$.

Kulcsszavak: veleszületett, defektus, maxillofacialis, maxillofacialis deformitás, genetika, megelőzés, ajakhasadék, szájpadhasadék, anatómia, terápia, epidemiológia, szülészet, sebészet

\section{Clinical aspects of congenital maxillo-facial deformities}

The cleft lip and palate deformity is one of the most common type of congenital abnormalities. The aim of this paper is to summarise the literature knowledge about cleft lip and/or palate. The authors review and discuss international literature data on the prevention, genetic and environmental predisposing factors, anatomical and embryological features, as well as pre- and post-natal diagnosis and treatment of these deformities. The aetiology is multifactorial, driven by both genetic and environmental factors which lead to multifaceted phenotypes and clinical features of these malformations. The lack of the multidisciplinary knowledge about prenatal diagnosis, prevention, genetic aspects and treatment strategy could result in serious diagnostic errors, hence clinical teamwork is critically important to solve the problems of this pathology. Only the professional teamwork and multidisciplinary cooperation can guarantee the optimal level of health care and better quality of life for these patients and their families.

Keywords: congenital defect, abnormality, maxillofacial, maxillo-facial, deformity, genetics, prevention, cleft lip, cleft palate, anatomy, therapy, epidemiology, counselling, obstetrics, surgery

Sólya, K., Dézsi, Cs., Vanya, M., Szabó, J., Sikovanyecz, J., Kozinszky, Z., Szili, K. [Clinical aspects of congenital maxillo-facial deformities]. Orv. Hetil., 2015, 156(37), 1483-1490.

(Beérkezett: 2015. június 25.; elfogadva: 2015. július 23.) 


\section{Rövidítések}

$2 / 3 / 4 \mathrm{D}=2 / 3 / 4$ dimenziós ultraszonográfia $; \mathrm{BMI}=($ body mass tndex) testtömegindex; $\mathrm{BMP}=$ bone morphogenic protein; Cor.Coef $=$ correlation coefficient; $\mathrm{CpG}$ dinukleotid $=\mathrm{az}$ örökítőanyag citozin-guanin párjai; DNS = dezoxiribonukleinsav; E = egészséges magzatokat világra hozó anyák kontrollcsoportja; $\mathrm{K}$ = koraszülésre pozitív anamnézisű kontrollanyák

$\mathrm{K}+\mathrm{V}=$ koraszülésre és vetélésre pozitív anamnézisú kontrollanyák; $\mathrm{V}$ = vetélésre pozitív anamnézisú anyák; FGF = fibroblast growth factor; FGF R2/R3 = fibroblast growth factor receptor; FISH = fluoreszcens in situ hibridizáció; FMF = Fetal Medicine Foundation; GF = (growth factor) növekedési faktor; HGNC $=$ HUGO Nomenclature Committee; IUGR $=($ int rauterine growth restriction) méhen belüli növekedési retardáció; MAP-kináz = mitogén aktiválta proteinkináz; mg = milligramm; missed $\mathrm{AB}=$ (missed abortion) embrionális elhalás, amelyet nem követ azonnal vetélés; $\mathrm{NF}=$ nuchal fluid; $\mathrm{NT}=$ nuchal translucency; OGTT = orális glükóztolerancia-teszt; $\mathrm{P}=$ (probability) valószínúség; $\mathrm{PCR}=($ polymerase chain reaction) polimeráz láncreakció; PLC = foszfolipáz-C; RNS = ribonukleinsav; SZTE = Szegedi Tudományegyetem; TGF = transforming growth factor; $\mathrm{UH}=$ ultrahang; $\mathrm{USG}=$ ultrasonography screening for gravid; VRONY = Veleszületett Rendellenességek Országos Nyilvántartása

Az arc komplex, a koponya elülső részét képező testtáj, amely az emberi test legspecifikusabb részeként az ember egyediségéért felelős, szerkezeti épsége és esztétikai minősége alapvető az egyén testi-lelki jóllétéhez. Hazánkban a születések 6\%-ában a magzat minor vagy major fejlődési rendellenességgel jön világra, amelyek jelentős hányada $(3,8-6,5 \%)$ az arckoponya rendellenességeit képviseli. Kiemelt jelentőséggel bírnak az ajak- és száj- padhasadékok, amelyek a Down-szindrómát követő második leggyakoribb congenitalis malformatiók, így a legygyakoribb congenitalis malformatiók között tartjuk számon [1]. Az arckoponya rendellenességei létrejöhetnek izolált formában, de az esetek egyharmadában szindróma részeként és/vagy egyéb genetikai betegségekkel kombinációban alakulnak ki $[2,3]$.

Célul tűztük ki az alábbi összefoglalóban, hogy részletesen bemutassuk az arckoponyát érintő szindrómás és nem szindrómás fejlődési rendellenességeket, amelyek praenatalis diagnosztikája még mindig csak az esetek 2030\%-ában valósul meg (1.ábra) [4]. Segítséget kívánunk nyújtani a klinikus és családorvos számára e speciális esetekben történő esetleges első vonalbeli tanácsadásban, még a terhesség alatt vagy a perinatalis időszakban.

$\mathrm{Az}$ arcdeformitások leggyakoribb típusa a maxillofacialis anomáliák a labium leporenum (ajakhasadék, chelioschisis vagy nyúlajak, angolul cleft lip) és/vagy a faux lupina (szájpadhasadék, palatoschisis vagy farkastorok, angolul cleft palate). Előfordulhatnak izolált vagy kombinált formában, illetve egy- vagy kétoldali lokalizációval. A rendellenesség a szoptatással, a beszéd és a hallás kialakulásával, illetve a személyiségfejlődéssel kapcsolatos problémákat is okozhat. Gyakran több diszciplína szakértőinek (fül-orr-gégész, plasztikai sebész, arcsebész, fogász, logopédus, gyermekgyógyász, genetikus, pszichológus, szakápoló és szociális munkás) együttmúködésére van szükség az optimális terápia és rehabilitáció elérése érdekében [5].

A maxillofacialis anomáliák multifaktoriális eredetűek, azaz kialakulásukban bizonyos, a terhesség alatt exponálódó külső tényezők (dohányzás, alkohol, gyógyszerek,

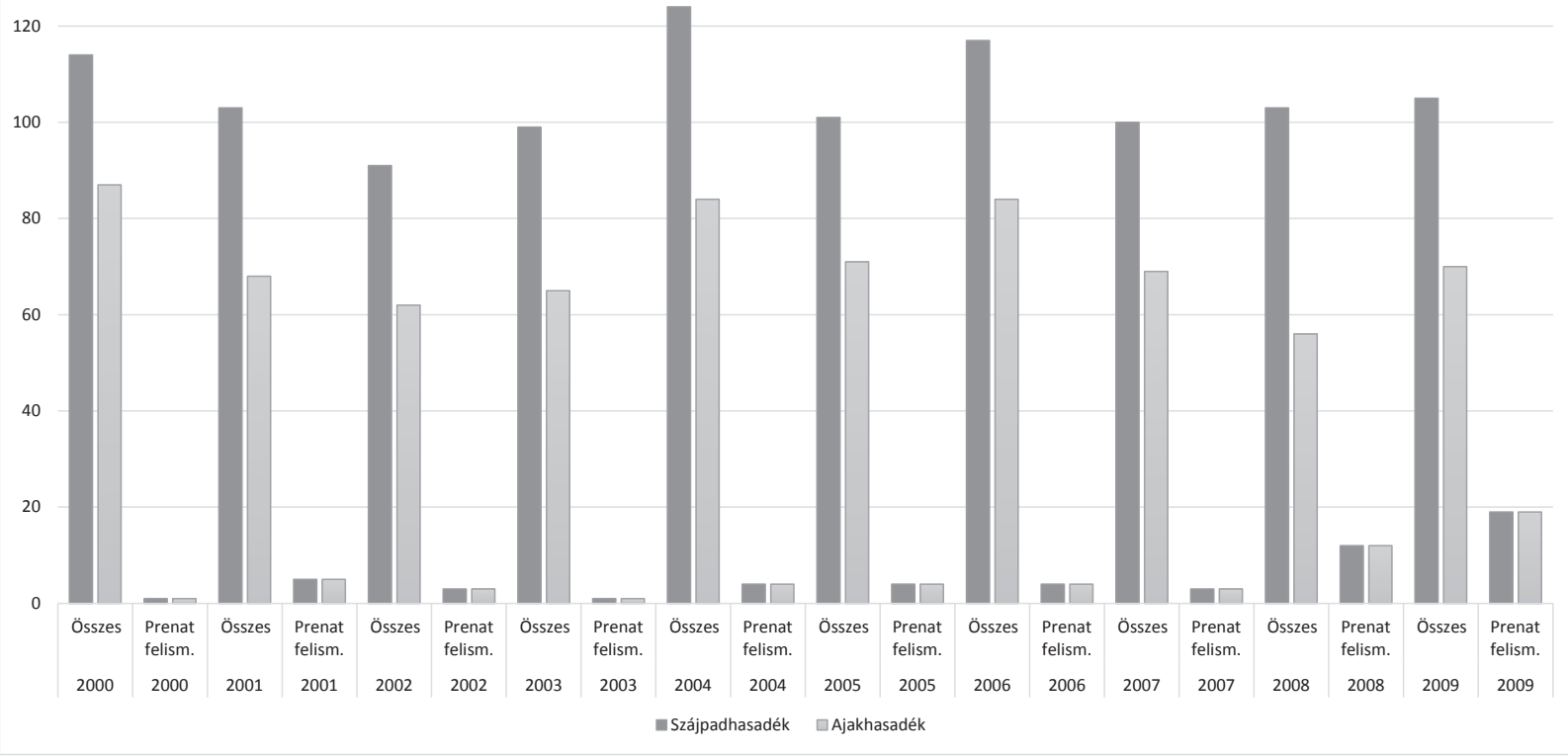

1. ábra | Izolált szájpad- és ajakhasadékok gyakorisága 2000-2009 között (VRONY 2011 alapján) 
1. táblázat | A szájpadhasadékok osztályozása

\begin{tabular}{ll}
\hline Veau & I. osztály: inkomplett, csak a lágy szájpad érintett \\
& II. osztály: a másodlagos szájpad érintett, kemény és \\
& lágy szájpad is érintett \\
& III. osztály: komplett unilateralis szájpadhasadék: az \\
& elsódleges és másodlagos szájpad is érintett \\
& IV. osztály: komplett bilateralis szájpadhasadék \\
& mind az elsődleges, mind a másodlagos szájpad \\
& érintettségével \\
& Ajak, alveolus, kemény szájpad, lágy szájpad, \\
& kemény szájpad, alveolus, ajak mentén jobbról balra \\
Lahshal & haladva \\
& A felső index a komplett szájpadhasadékra utal \\
& Az alsó index az inkomplett szájpadhasadékra utal \\
& X betú a normális struktúrát jelöli \\
Striped Y & Y alakú diagramon jeleníti meg az elváltozásokat, \\
& ahol az Y jelzi a komplett bilateralis \\
& szájpadhasadékot, ahol a kemény és a lágy szájpad is \\
& érintett, alosztályokat elkülönítve l-tól 9-ig, ahol az \\
& elváltozás mértékét pontozva berajzolják \\
Az embriológiai állapotokat veszi alapul: \\
Tessier
\end{tabular}

narkotikumok), illetve az esetek 30-50\%-ában genetikai hajlamosító tényezők (1. táblázat), vagy ezek együttesen játszanak szerepet [6]. A környezeti tényezók közül az anya életkora (<20 év vagy >39 év), anyai stressz, elhízás, az apa magas életkora, az anya betegsége (diabetes mellitus, magas vérnyomás, vírusbetegségek [rubeola, Parvo B13], cink-vagy folátanyagcsere-defektus) szerepel hozzájáruló tényezőként. A cink a neuronalis migrációban játszik szerepet [7] és hiánya fokozza az orofacialis defektusok kialakulásának kockázatát [8]. A molekuláris faktorok közül a csontosodásban és a csontok záródásában szerepet játszanak a növekedési faktorok, citokinek (bone morphogenic factor 4, fibroblast growth factor receptor 2, transforming growth factor, IRF6, ch8q24, VAXI) defektusai [6].

Teratogén hatású faktorok közül az anya káros szenvedélye (dohányzás, alkoholfogyasztás), A-vitamin, valproát, rovarirtó szerek, mérgező anyagok emelhetők ki, valamint az anya foglalkozási ártalma (például bőrfeldolgozás, cipőkészítő) lehet jelentős az első trimeszterben $[6,9]$.

A magasabb kortizolszint az első trimeszterben 3,4-szeresére emeli a szájpadhasadék kockázatát, mivel az extracelluláris mátrix szerkezetét átalakítja és ezzel a szájpadnyúlványok növekedését befolyásolja. Az antiepileptikumok szintén elősegítik a szájpadhasadék kialakulását (például a fenitoin tízszeresére emeli a kockázatot) $[9,10]$. A dohányzás önmagában kétszeresére növeli a szájpadhasadék kockázatát, amelyet bizonyos gének (TGF- $\alpha$ és MSXI) specifikus alléljainak előfordulása tovább növel. Kortizol szempontjából fontos kiemelni a gyász állapotát, amely fokozott kortizoltermeléssel jár, így növeli a maxillofacialis anomáliák kialakulásának kockázatát $[11,12]$.

A maxillofacialis defektusok családi halmozódást mutatnak. Ajakhasadékok esetén ha egy családban egy szülőben vagy egy gyermekben jelen van, akkor az ismétlődés kockázata 4\%, míg az egyik szülő és egy gyermek együttes érintettsége esetén 17\% [1]. Ha az egyik szülő érintett, akkor 3-5\% a kórképpel született gyermekek aránya, míg ha egy gyermek és egy másik rokon családon belüli betegsége esetén a következő gyermek esélye 15\% e fejlődési rendellenesség kialakulására [1, 13].

Magyarországon 2011-ben 101 esetet regisztráltak, amelynek 34,7\%-a izolált szájpadhasadék, 46\%-a izolált ajakhasadék, míg 18,8\%-a kombinált eset volt. Az ajak az esetek több mint 60\%-ában érintett (1. ábra) [4, 14, 15]. Egyéb orofacialis deformitások, amelyek érinthetik az orrot, a szemet, a fület, illetve a homlokot, csak elvétve fordulnak elő. A craniofacialis anomáliák előfordulása nagy földrajzi sajátosságokat mutat, Amerika bizonyos területein 3\%o feletti, Ázsiában ezer újszülöttből kettő, míg Európában egy újszülöttön diagnosztizálható arcfejlődési rendellenesség [2]. Az ajakhasadékok gyakoribbak fiú magzatokban, és a kombinált esetek aránya is $2: 1$ a fiúk javára, míg a szájpadhasadék lányoknál gyakoribb ugyanilyen arányban [16]. Lányoknál a szekunder szájpadot kialakító szájpadnyúlványok egyesülése egy héttel tovább tart, ami több lehetőséget ad a teratogén hatások kifejtésére $[2,17,18,19,20]$. Mindkét nemben az ajak vagy a primer szájpad bal oldala érintett gyakrabban [2].

$\mathrm{Az}$ intrauterin 4. héttől indulnak növekedésnek az arcnyúlványok (1 frontonasalis, 2 maxillaris és 2 mandibularis) néhány homeobox fehérje hatására [17], amelyeknek patológiás fejlődésével és összenövésének hiányával jönnek létre a hasadékok $[5,21]$. A felső állcsonti nyúlvány az első garatív hátsó részéből fejlődik ki, és belőle alakul ki a maxilla, míg az első garatív elülső része adja a mandibularis nyúlványt, amelyből az alsó állkapocs fejlődik ki. A felső ajkat a két medialis orrnyúlvány és a két maxillaris nyúlvány egyesülése hozza létre. Az orr kialakulása a frontonasalis nyúlványból a medialis és lateralis orrnyúlványokból történik. A medialis orrnyúlványok egyesüléséből alakul ki a filtrum a 6 . hét végén, majd az orrnyúlványok egyesülnek a maxillaris nyúlványokkal, a 6-8. hét végére, kialakítva ezzel az intermaxillaris szegmentet, amely a primer szájpadot, a 4 metszőfogat és a felső ajak középső részét adja. A felső állkapocsnyúlvány kinövései a processus palatinalisok, avagy szájpadnyúlványok, amelyek a 6. héten jelennek meg, és hátrafelé és középvonal felé összenőve kialakítják a szekunder palatumot, ami előrefelé fuzionál a primer szájpaddal (a 6-12. hét között). A két szájpad közötti határ a foramen incisivum $[1,5,6,17,19,22,21,23]$.

A hasadékok a gesztáció 5 . és 12. hete között alakulnak ki. Az ajak-, illetve a szájpadhasadék eltérő embriológiai hátterü $[5,19,22,24]$. A hasadék nagysága és kialakulásának időpontja alapján különböző súlyosságú formák képződhetnek. Az izolált ajakhasadékok kialaku- 
2. táblázat A leggyakoribb monogénes betegségek ajak- és/vagy szájpadhasadékkal

\begin{tabular}{|c|c|c|}
\hline Locus & Érintett gén/hatás & Fenotípus/szindróma \\
\hline $\operatorname{lp} 21.1$ & COLl1Al & Stickler-szindróma típus II \\
\hline $1 q 32.3-q 41$ & IRF6 & $\begin{array}{l}\text { Poplitealis pterygium } \\
\text { szindróma }\end{array}$ \\
\hline $\operatorname{lp} 34$ & WDR65 & Van der Woude-szindróma \\
\hline $1 \mathrm{p} 36.11$ & GRHL3 & Van der Woude-szindróma \\
\hline $1 q 32-q 41$ & IRF6 & Van der Woude-szindróma \\
\hline $2 \mathrm{p} 21$ & SIX3 & Holoprosencephalia-2 \\
\hline $2 \mathrm{p} 25.3$ & COLECI1 3 & MC-szindróma \\
\hline $2 \mathrm{q} 14.2$ & GLI2 & Holoprosencephalia-9 \\
\hline $2 q 31.1$ & GADl & $\begin{array}{l}\text { Cerebralis palsy Spasticus } \\
\text { quadriplegica }\end{array}$ \\
\hline $2 q 33.1$ & SATB2 & $\begin{array}{l}\text { Pierre Robin-szekvencia } \\
\text { ankyloglossiával vagy a nélkül }\end{array}$ \\
\hline $2 q 33.1$ & SATB2 & Szellemi fogyatékosság \\
\hline $3 q 27$ & ТP63 & $\begin{array}{l}\text { Ectodermalis ectrodactylia } \\
\text { dysplasia } \mathrm{CL} / \mathrm{P}\end{array}$ \\
\hline $3 q 27.3$ & MASPl 3 & MC-szindróma \\
\hline $3 q 28$ & TP63 & EEC3 \\
\hline $3 q 28$ & ТP63 & $\begin{array}{l}\text { Ankyloblepharon-ectodermal } \\
\text { defektus-Clefting (AEC) } \\
\text {-szindróma }\end{array}$ \\
\hline $3 q 28$ & TP63 & Limb-Mammary-szindróma \\
\hline $3 q 28$ & TP63 & Orofacial cleft 8 (OFC8) \\
\hline $3 \mathrm{q} 28$ & TP63 & Rapp-Hodgkin-szindróma \\
\hline $4 \mathrm{pl} 6.2$ & MSXl & Fogagenesia \\
\hline $4 \mathrm{pl} 6.2$ & MSXl & CLP fogászati eltérés nélkül \\
\hline $4 \mathrm{pl} 6.2$ & MSXl & Witkop-szindróma \\
\hline $4 \mathrm{pl} 16.3$ & FGFR3 & $\begin{array}{l}\text { Crouzon/Wolf-Hirschhorn- } \\
\text { szindróma (WHS) }\end{array}$ \\
\hline $5 \mathrm{pl} 13.2$ & NIPBL & $\begin{array}{l}\text { Cornelia de Lange- } \\
\text { szindróma }\end{array}$ \\
\hline $5 q 15-q 21$ & $\mathrm{CDHl}$ & $\begin{array}{l}\mathrm{CL} / \mathrm{P} \text { és gyomorrák gastric } \\
\text { cancer }\end{array}$ \\
\hline $5 q 32$ & TCOFl & $\begin{array}{l}\text { Treacher Collins-szindróma } \\
\text { szembetegséggel }\end{array}$ \\
\hline $6 \mathrm{p} 21.32$ & COL11A2 & Stickler-szindróma típus II \\
\hline $6 q 22.31$ & GJAl & $\begin{array}{l}\text { Oculodentodigital dysplasia } \\
\text { (ODDD) CL } / \mathrm{P}-\mathrm{lel}\end{array}$ \\
\hline $6 \mathrm{p} 24$ & TFAP2A & $\begin{array}{l}\text { Branchio-oculofacialis } \\
\text { szindróma }\end{array}$ \\
\hline $7 \mathrm{p} 21$ & TWISTl & Saethre-Chotzens-szindróma \\
\hline $7 \mathrm{q} 21.11$ & SEMA3E & CHARGE-szindróma \\
\hline $7 \mathrm{q} 36.3$ & SHH & Holoprosencephalia-3 \\
\hline $8 \mathrm{pll} .23-\mathrm{pl} 1.22$ & FGFRl & Kallmann-szindróma \\
\hline $8 \mathrm{pll} .23-\mathrm{pl} 1.22$ & FGFRl & Non-syndromic CLP \\
\hline $8 \mathrm{q} 12.1-\mathrm{q} 12.2$ & CHD7 & CHARGE-szindróma \\
\hline
\end{tabular}

\begin{tabular}{|c|c|c|}
\hline Locus & Érintett gén/hatás & Fenotípus/szindróma \\
\hline $8 \mathrm{q} 13.3$ & EYAl & $\begin{array}{l}\text { Branchiootorenal szindróma } \\
\text { típus I }\end{array}$ \\
\hline $8 \mathrm{q} 24.21$ & MYC & Burkitt-lymphoma \\
\hline $9 \mathrm{q} 22$ & FOXE1 & $\begin{array}{l}\text { Bamforth-Lazarus- } \\
\text { szindróma }\end{array}$ \\
\hline $9 \mathrm{q} 22.32$ & PTCHI & Holoprosencephalia-7 \\
\hline $9 q 31$ & PTCHl & Gorlin-Göetz-szindróma \\
\hline $10 \mathrm{q} 25$ & SMC3 & $\begin{array}{l}\text { Cornelia de Lange- } \\
\text { szindróma }\end{array}$ \\
\hline $10 \mathrm{q} 26.13$ & FGFR2 & $\begin{array}{l}\text { Crouzon-Apert-Pfeiffer- } \\
\text { szindróma }\end{array}$ \\
\hline $10 \mathrm{q} 26.13$ & FGFR2 & Non-syndromic CLP \\
\hline $11 p 15$ & $\begin{array}{l}\text { IGF-2 és } \\
\text { CDKNIC }\end{array}$ & Beckwith-Wiedermann \\
\hline $11 \mathrm{q} 23.3$ & PVRLl & $\begin{array}{l}\text { CLP ectodermal dysplasia } 1 \\
\text { (CLPEDl) }\end{array}$ \\
\hline $11 \mathrm{q} 23.3$ & PVRLl & Nem szindrómás CLP \\
\hline $11 \mathrm{q} 24.2$ & CDON & Holoprosencephalia-11 \\
\hline $12 \mathrm{q} 12-\mathrm{q} 14$ & MLL2 & Kabuki-szindróma \\
\hline $12 \mathrm{q} 13.11$ & COL2Al & Stickler-szindróma típus I \\
\hline $13 q 32.3$ & ZIC2 & Holoprosencephalia-5 \\
\hline $14 \mathrm{q} 13.3$ & PAX9 & Fogagenesia \\
\hline $14 \mathrm{q} 23.1$ & SIXl & $\begin{array}{l}\text { Branchiootorenalis } \\
\text { szindróma III. típus }\end{array}$ \\
\hline $15 \mathrm{q}_{12}$ & GABRB3 & Childhood absence epilepsy \\
\hline $16 \mathrm{q} 22.2$ & DHODH & Miller-szindróma \\
\hline $17 \mathrm{p} 13.3$ & $\begin{array}{l}\text { mikródeléciós } \\
\text { szindróma: } \\
\text { PAFAH1B1, } \\
\text { YWHAE, LIS1, } \\
\text { 14-3-3e }\end{array}$ & $\begin{array}{l}\text { Miller-Dieker-lissencephalia } \\
\text { szindróma }\end{array}$ \\
\hline $17 \mathrm{q} 24.3$ & SOX9 & $\begin{array}{l}\text { Pierre Robin-szindróma with } \\
\text { or without campomelic } \\
\text { dysplasia }\end{array}$ \\
\hline $18 \mathrm{pll} .31$ & TGIF & Holoprosencephalia-4 \\
\hline $19 \mathrm{q} 13.32$ & SIX5 & $\begin{array}{l}\text { Branchiootorenal szindróma } \\
\text { típus II }\end{array}$ \\
\hline $21 \mathrm{q} 22.3$ & RIPK4 & Bartsocas-Papas-szindróma \\
\hline $\begin{array}{l}22 \mathrm{q} 11.2 \\
22 \mathrm{q} 11.2\end{array}$ & $\begin{array}{l}\text { deletion } \\
\text { szindróma }\end{array}$ & $\begin{array}{l}\text { DiGeorge-szindróma, } \\
\text { velocardiofacial szindróma }\end{array}$ \\
\hline $22 \mathrm{q} 11.21$ & TBXI & Velocardiofacial szindróma \\
\hline Xp11.22-p11.21 & SMCIA & $\begin{array}{l}\text { Cornelia de Lange- } \\
\text { szindróma }\end{array}$ \\
\hline Xp22.31 & KALl & Kallmann-szindróma \\
\hline $\mathrm{Xq} 21.1$ & TBX22 & $\begin{array}{l}\text { Cleft palate with or without } \\
\text { ankyloglossia }\end{array}$ \\
\hline $\mathrm{Xq} 21.1$ & TBX22 & $\begin{array}{l}\text { Abruzzo-Erickson- } \\
\text { szindróma }\end{array}$ \\
\hline $\mathrm{Xq} 21.1$ & TBX22 & Hypodontia \\
\hline $\mathrm{Xq} 28$ & FLNA & Otopalatodigital szindróma \\
\hline $\mathrm{Xq} 28$ & FLNA & Facialis állapotok \\
\hline
\end{tabular}


lásakor a felső állkapocsnyúlvány és a medialis orrnyúlvány nem fuzionál, amelyek a 4-5. embrionális héten alakulnak ki. A kombinált ajak- és szájpadhasadék a primer szájpad fejlődési rendellenessége. Izolált szájpadhasadék előfordulhat a felső állcsonton, a primer és a szekunder szájpad között vagy a szekunder szájpadon (a foramen incisivum mögött), amikor a két szájpadnyúlvány egyesülése marad el (rendszerint később, a 10-12. héten alakulnak ki). Az elsődleges és másodlagos szájpad együttes fejlődési zavara a komplett ajak-állcsont-szájpad hasadék.

Az arcfejlődési defektusok lehetnek nem szindrómás esetek (izolált) vagy genetikai szindróma részei (2. táblázat) [25]. A Goldenhar-szindróma (craniofacialis microsomia) részjelensége is lehet hasadék, de eredete ismeretlen [26]. Több mint 300 genetikai tünet együttes része a szájpadhasadék vagy a kombinált ajak/szájpad hasadék (2. táblázat), amelyek mintegy fele monogénes öröklésmenetet mutat (50\%-ban autoszomális domináns, 40\%ban autoszóm recesszív és 10\%-ban X-kromoszómához kötött). Megjelenésében a mendeli öröklésmenet egyéb aspektusai, mint a csökkent penetrancia, variábilis génexpresszió, imprinting, allél- és locusheterogenitás is szerepet kap [17]. A leggyakoribb hasadékokat magába foglaló Van der Woude-szindróma hátterében az interferonregulátoros faktor 6 génmutációja áll, amely jelentős szerepet játszik a szájpadnyúlványok fúziójában [27]. Több szindróma esetében a szájpadhasadék csak másodlagos következménye a patológiás arc- és nyelvnövekedésnek (például Pierre Robin-szekvencia) [13]. Sok esetben bizonyos kromoszómadefektus (deléció, duplikáció, illetve triszómia) vezet a szindróma kialakulásához. A velocardiofacialis szindróma és a conotruncalis anomalia arcszindróma hasonló fenotípusúak, és mindkettőt a 22q11.2 locus deléciója okozza [17].

Összességében véve a kromoszóma-rendellenességek gyakorisága egyoldali hasadékok esetében 32\%, míg kétoldali esetben 59\%. A kromoszómaaneuploidiák közül leggyakrabban a 21-es, 18-as és 13-as kromoszóma triszómiája társul maxillofacialis defektusokkal [13].

Mind a nyúlajak, mind a szájpadhasadék jelentősen változatos morfológiájú. A nyúlajak is érintheti a felső ajkat vagy ezen túlmenően még az alveolusokat, illetve a szájpad elülső részét [23]. A nyúlajak morfológiáját tekintve megkülönböztetünk a) mikro formát, b) inkomplett és c) komplett formát (az ajak mellett gyakran az alveolus is érintett), amelyek a genetikai háttérrel állhatnak összefüggésben $[5,22,24]$. A szájpadhasadék attól függően is változatos morfológiájú és érintettségü lehet, hogy egy- vagy kétoldali.

A szájpadhasadék érintheti az elsődleges szájpadot, amely a foramen incisioum előtt helyezkedik el, de érintheti a másodlagos szájpadot is [13]. A kemény szájpad deficientiája a csontos részek kóros fejlődését jelenti, míg a lágy szájpad érintettsége a nyálkahártya, az izomzat musculus (m.) levator veli palatini, m. tensor veli palati$n i, m$. palatopharyngeus, $m$. palatoglossus és az uvula musculaturája - nem megfelelő fejlődését foglalja magába $[20,28]$. Ezek az izmok gallért képeznek és a nasopharynx zárásában vesznek részt beszéd esetén és nyeléskor, illetve az Eustach-kürt megfelelő funkciójához elengedhetetlenül szükségesek. Szájpadhasadék esetén ezek az izmok hiányozhatnak, gyengén fejlettek vagy rossz helyen tapadhatnak, amely a szájpad csökkent funkcióját okozza, illetve velopharyngealis insufficientiához (VPI) vezet [13]. A legkisebb problémát az izolált submucosus forma jelenti, ahol a szájpadizomzat vagy bypoplasiás, vagy rossz helyen tapad, és jellemző rá a hasadt uvula és a zona pellucida (kék színú középső rész és a kemény szájpad hátsó részén elhelyezkedő csomó) [29]. A szájpadhasadékok osztályozását az 1. táblázat mutatja be. A leggyakrabban használt beosztás a Veauklasszifikációs szisztéma $[20,30]$. Az anatómiai képleteket figyelembe vevő beosztás mindig előnyösebb a sebészeti beavatkozások szempontjából, viszont az embriológiai klasszifikáció a genetikai információ szempontjából fontos $[9,10]$. Kombinált hasadékok esetében a felső ajak mellett az alveolusok, illetve a szájpad is érintett $[6,23]$.

\section{Megelőzés}

Az orofacialis fejlődési rendellenességek megelőzésében a folsavnak lehet szerepe. Az első trimeszterbeli folátszupplementáció egyharmadtól [31] háromnegyed [32] arányban csökkentette a hasadékok előfordulását, habár nem minden tanulmány tudta ezt igazolni [33].

\section{Arcfejlődési rendellenességek ultrahang-diagnosztikája}

Az arcnyúlványok fúziója a 4-8. terhességi hét között jön létre, így akár a 2 hónapos magzaton megállapítható ultrahanggal a deformitás [1]. A kemény szájpad egyedisége miatt személyazonosításra is alkalmas lehet, akár a magzati kortól kezdve [34]. A második trimeszterben válik lehetővé a magzat arcának vizsgálata. Erre a legalkalmasabb síkok:

- coronalis - fóként a maxilla és az ajak szerkezetének vizsgálata,

- sagittalis - orrcsont,

- transversalis - a mandibula és kemény szájpad ábrázolása.

A bilateralis defektusok 2 dimenziós rutinvizsgálaton is felismerhetőek. Középvonali ajakhasadékok módosított coronalis nézetben ábrázolhatók. A legnehezebben felismerhető az izolált szájpadhasadék. A magzat mimikájának megfigyelésére ad lehetőséget a 3/4 D ultrahang. Arckoponya-defektusok esetében kiemelendő a nyelés, szájnyitás vizsgálata (2. ábra). Doppler-ultrahanggal az amnion szájüregból orrüreg felé való áramlása vizsgálható, kóros áramlás hasadékra gyanús. Az áramlás rendellenességének mértéke korrelál a hasadék 




2. ábra | Magzati ajakhasadék 4D ultrahangképe

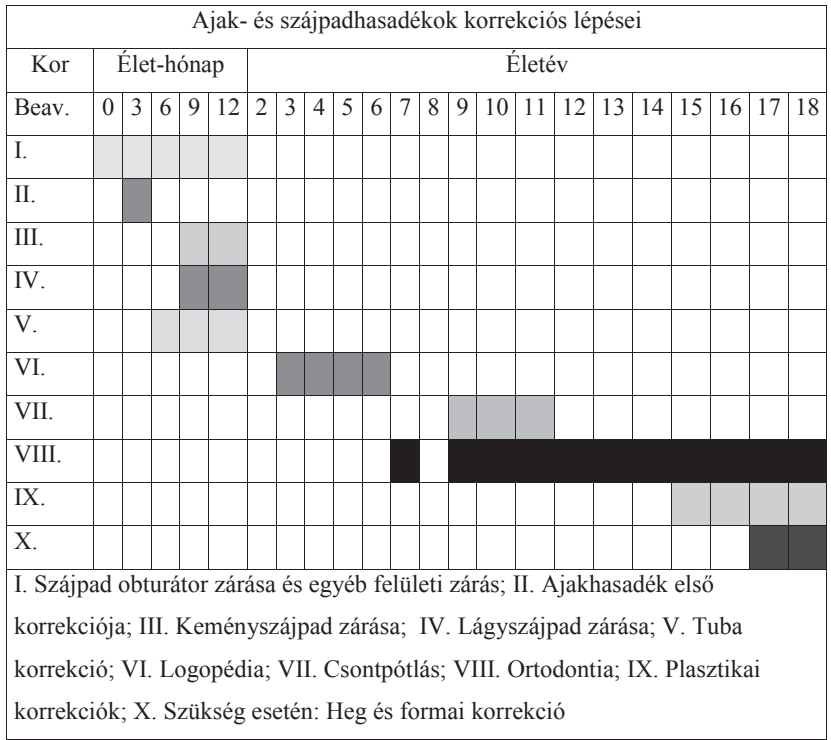

3. ábra Ajak- és szájpadhasadék terápiás lehetőségi kor szerint

kiterjedésével. A pontos képalkotáshoz és a magzat vizsgálatához elengedhetetlen az orvos gyakorlata, tapasztalata és türelme, mivel a magzat nem mindig helyezkedik el az adott vizsgálathoz szükséges pozícióban.

\section{Magzati diagnosztika és genetikai tanácsadás}

A genetikai tanácsadás célja, hogy megállapítsa és lehetőség szerint megmagyarázza a fokozott genetikai kockázatot, illetve annak lehetőségét, ezenfelül, hogy megfelelő szakmai tájékoztatást adjon a genetikai betegségek szűrési és diagnosztizálási lehetőségeiről. Magyarországon régóta zajlik a terhesek gondozása, ennek részévé vált a genetikai tanácsadás, valamint a citogenetikai és molekuláris genetikai vizsgálatok. A családban ismert fejlődési rendellenességek ismétlődési kockázatának tisztá- zására a családtervezőknek is javasolt a genetikai tanácsadáson való részvétel, amely az ismétlődési kockázat becslésén túl a prevenciós lehetőségekről is hasznos információkkal szolgálhat [35].

\section{Postnatalis klinikai vonatkozások}

A deformitások különböző módon és mértékben befolyásolják a magzat és a megszületett gyermek szervrendszereit. A leggyakoribb problémák közé tartozik a táplálási, étkezési nehézség, beszéd-hangképzési nehézség, fogászati problémák, hallórendszeri infekciók, illetve a hallás- és szaglászavar. A rendellenességek a csecsemő növekedésével egyre nagyobb problémát jelentenek, illetve rontják a beteg életminőségét és olykor életkilátásait is, ezért indokolt születés után minél előbb megkezdeni a rekonstrukciót.

\section{Terápiás lehetőségek}

A terápia és ellátás tervezése a diagnózis (genetikai tanácsadás) pillanatában el kell kezdődjön. Az ellátás első lépése a szülők informálása más potenciálisan fennálló rendellenességekről, azok vizsgálatáról, kizárásáról, a születendő gyermek speciális igényeiről, a kuratív terápiás lehetőségekről és ezek anyagi és pszichés, valamint szociális hatásairól. A kezelés multidiszciplináris csapat feladata, amelynek tagjai gyermeksebész, fül-orr-gégész, logopédus, szájsebész, fogorvos és pszichológus, habár a hasadékok elsődleges terápiája a sebészeti zárás. A mútét előtt fel kell mérni az újszülött fizikai állapotát, tudatában kell lenni az esetleges kontraindikációs tényezóknek, ezért a szülőknek érdemes még az újszülött érkezése előtt lehetőséget biztosítani a terápiás csapattal való konzultációra. Ennek keretében ki kell térni a defektus típusára, a rendellenesség potenciális okaira, a mütéti terápia idejére, menetére, részleteire. A korrekció több lépésből áll, amelyet a 3. ábra mutat be [36]. Nem vethető alá rekonstrukciónak az újszülött, ha alultáplált, vérszegény vagy ha elégtelenek a légzési és keringési paraméterei. A szülés után a csecsemő megfelelő táplálása érdekében az újszülöttnek egyénre szabott szájpadlemez készül. Egészséges, élettani paraméterekkel rendelkező újszülött 3 hónapos korban vethető alá a korrekciós mútétnek. A hasadékzárás lehetséges technikái közül a leggyakrabban alkalmazottak: az egyenes vonalú zárás, a hullámvonalú zárás és a Z-plasztika [13].

Másodlagos mútéttel eltüntethető az esetlegesen viszszamaradt heg, az ajak-, illetve ajakpír további korrekcióival javítható az arc esztétikája. Végleges korrekcióra általában a tinédzserkor elérése után kerül sor. A hasadékok sebészeti korrekciója mindig az adott anatómiai helyzettől függ. A komplett ajakhasadékokat a sebészeti beavatkozás előtt leragasztják vagy egyéb eljárásokkal összehúzzák a sebszéleket [36] az első élethónapban, hogy morfológiailag inkompletté váljanak, és ne kelljen a végleges mútét alkalmával nagy húzóerőt kifejteni, majd 
3. táblázat $\mid$ Az ajakpadhasadékok mútéti reparációjának lehetőségei [6]

\begin{tabular}{ll}
\hline $\begin{array}{l}\text { Egyenes vonalú } \\
\text { zárás }\end{array}$ & $\begin{array}{l}\text { A mikro formák esetében használatos. Általában } \\
\text { csomó alakul ki az ajakban, illetve kontraktúra } \\
\text { a sebszélben, amit különböző irányból eredö } \\
\text { ajaklebenyek közbeiktatásával lehet kiküszöbölni. }\end{array}$ \\
$\begin{array}{l}\text { Geometriai } \\
\text { lebenyplasztika }\end{array}$ & $\begin{array}{l}\text { Alkalmas széles defektusok mútétjére, amikor } \\
\text { különféle alakzatú lebenyek segítségével húzzuk } \\
\text { össze a sebszéleket. A hátránya a csökkent } \\
\text { flexibilitás és a hegképződés. }\end{array}$ \\
$\begin{array}{l}\text { Millard-féle } \\
\text { rotációs } \\
\text { lebenyplasztika }\end{array}$ & $\begin{array}{l}\text { Medialis ajakrészt lefelé forgatják, miközben } \\
\text { lebenyt a lateralis ajakrészből képeznek. }\end{array}$ \\
\hline
\end{tabular}

4. táblázat |A szájpadhasadékok mútéti reparációjának lehetőségei [24]

\begin{tabular}{|c|c|}
\hline $\begin{array}{l}\text { Von Lagenback- } \\
\text { módszer }\end{array}$ & $\begin{array}{l}\text { A szekunder szájpad inkomplett hasadékánál } \\
\text { használják. Kétoldali mucoperiostealis lebenyek } \\
\text { medialisan történő zárása. }\end{array}$ \\
\hline $\begin{array}{l}\text { Intravelaris } \\
\text { veloplasztika }\end{array}$ & $\begin{array}{l}\text { A patológiásan tapadó velaris (lágy szájpad) } \\
\text { izmok repozíciója a megfeleló anatómiai } \\
\text { pozícióba, hogy javítsák a velaris és } \\
\text { torokfunkciót. }\end{array}$ \\
\hline $\begin{array}{l}\text { VY pushback } \\
\text { palatoplasztika } \\
\text { (vagy Veau- } \\
\text { Wardill-Kilner- } \\
\text { plasztika) }\end{array}$ & $\begin{array}{l}\text { A szájpad kétoldali mucoperiostealis } \\
\text { lebenyének felemelése és medialis és posterior } \\
\text { irányba történő hajtása, V-ből Y-ba történő } \\
\text { irányba és a m. levator veli palatini reparációja. } \\
\text { Célja a szájpad hosszabbítása, a lágy szájpad } \\
\text { mobilitásának növelése, illetve a velofaringealis } \\
\text { funkció helyreállításának elősegítése. }\end{array}$ \\
\hline $\begin{array}{l}\text { Kétlebenyes } \\
\text { palatoplasztika }\end{array}$ & $\begin{array}{l}\text { Egyoldali vagy kétoldali komplett } \\
\text { szájpadhasadékra használatos. A szájüregi } \\
\text { mucoperiostealis, illetve az orrüregi mucosalis } \\
\text { lebeny kipreparálása, megemelése és } \\
\text { középoldali zárása a m. levator veli palatini } \\
\text { reparációját követően. }\end{array}$ \\
\hline $\begin{array}{l}\text { Furlow-féle } \\
\text { szemben lévő } \\
\text { Z-palatoplasztika }\end{array}$ & $\begin{array}{l}\text { A lágy szájpad mútéti korrekciója és annak } \\
\text { meghosszabbítása. Négy háromszög alakú } \\
\text { lebeny képzése ( } 2 \text { lebeny jobb és bal oldalon } \\
\text { is) egy } \mathrm{Z} \text { vonal mentén úgy, hogy az egyik } \\
\text { oldalon és a másik oldalon is az elöl } \\
\text { kialakítandó lebenyben izom és nyálkahártya is } \\
\text { van, míg a hátul kialakítandó lebenyt csak } \\
\text { nyálkahártya alkotja. Az izmot tartalmazó } \\
\text { lebenyt hátra és középvonal felé és medialis, } \\
\text { míg a nyálkahártyát tartalmazó lebenyt előre és } \\
\text { középvonal felé húzzák. }\end{array}$ \\
\hline
\end{tabular}

később összevarrják a sebet (3-4. táblázat). Fontos, hogy az első sebészeti beavatkozás után ne alakuljon ki akkora mértékú heg, ami akadályozná a sebgyógyulást [37]. A sebészeti korrekció optimális időpontja a 10-12. hét [38]. Az ajakhasadékok korrekciójára szolgáló sebészeti beavatkozásokat a 3. táblázat foglalja össze.

A szájpadhasadékok esetében a palatoplasztika célja az, hogy a szájüreget az orrüregtől elválasszuk annak érdekében, hogy egy megfelelő velopharingealis gyưrüt hozzunk létre a beszédhez és a nyeléshez, illetve megelőzzük a túlzott haránt irányú arcközépi (midface growth) növekedést $[13,35,39]$. Az első cél eléréséhez a sebészeti beavatkozás optimális ideje a születés utáni 3-6. hónap, de mindenképpen 1 éven belül, míg a második cél elérése érdekében a 2-5 éves korban elvégzett mútét alkalmas, de nem később, mint 15 éves korban. A legtöbb sebész a 12-24. hónap között végzi el a beavatkozást [40]. A választott sebészeti eljárás függ attól, hogy az elsődleges vagy másodlagos szájpad érintett, milyen vastag a hasadék, szükség van-e a szájpad hosszabbítására, illetve, hogy milyen mértékű az arcközépi növekedés. Ismételt beavatkozásra is szükség lehet, hogy a beszéd, a nyelés és a fogképződés megfelelő legyen, illetve a sebészeti előtt ortopédiai kezelés is szükséges lehet [35]. A sebészeti beavatkozásokat a 4. táblázat foglalja össze $[23,29,35,40]$.

A műtéti szövődmények közé tartozik az oedema, oronasalis fistula, elzáródott légutak, nyelvischaemia, VPI, ami függ az életkortól és a korrigálandó elváltozás milyenségétől és mértékétől [13, 20,41]. A VPI előidézhet beszéd- és nyelési nehézségeket, nasalis regurgitatiót.

\section{Következtetések}

Az ajak- és szájpadhasadékok komplex szúrésénél, diagnosztikájánál és terápiájánál talán csak a megelőzésük fontosabb. A primer prevenció biztosíthatja egyedül föként a nem szindrómás esetek számának csökkenését.

Anyagi támogatás: A közlemény megírása, illetve a kapcsolódó kutatómunka anyagi támogatásban nem részesült.

Szerzôi munkamegosztás: Minden szerző együttesen járult hozzá a kézirat megszövegezéséhez és az irodalmi áttekintéshez. A cikk végleges változatát valamennyi szerző elolvasta és jóváhagyta.

A cikk dr. Sólya Kitti szakdolgozata alapján készült, témavezető dr. Szili Károly. Társ témavezetők: Prof. Dr. Szabó János, dr. Sikovanyecz János, dr. Vanya Melinda. Megosztott utolsó szerzők: dr. Kozinszky Zoltán, dr. Szili Károly. S. K. és D. Cs. kölcsönösen megállapodtak, hogy a publikáció egyes részeit felhasználhatják PhDdisszertációikban.

Érdekeltségek: A szerzőknek nincsenek érdekeltségeik.

\section{Irodalom}

[1] Sadler, T. W.: Langman's Medical Embryology. 13 ${ }^{\text {th }}$, North American ed. Wolters Kluwer Health, 2015. http://www.ncbi. nlm.nih.gov/pubmed/2012

[2] Gundlach, K. K., Maus, C.: Epidemiological studies on the frequency of clefts in Europe and world-wide. J. Craniomaxillofac Surg., 2006, 34(Suppl 2), 1-2.

[3] Calzolari, E., Pierini, A., Astolfi, G., et al.: Associated anomalies in multi-malformed infants with cleft lip and palate: An epide- 
miologic study of nearly 6 million births in 23 EUROCAT registries. Am. J. Med. Genet., 2007, 143A, 528-537.

[4] Métneki, J., Valek, A., Béres, J., et al.: National Registry of Inborn Anomalies. Report of the year 2009. [Jelentés a Veleszületett Rendellenességek Országos Nyilvántartása (VRONY) 2009. évi adatairól.] http://www.oefi.hu/vrony/vrony05.htm Országos Szakfelügyeleti Módszertani Központ, Veleszületett Rendellenességek Országos Felügyeleti Osztálya, Budapest, 2011. [Hungarian]

[5] Mossey, P. A., Little, J., Munger, R. G., et al.: Cleft lip and palate. Lancet, 2009, 374(9703), 1773-1785.

[6] Shkoukani, M. A., Chen, M., Vong, A.: Cleft lip - a comprehensive review. Front Pediatr., 2013, 1, 53. Doi: 10.3389/ fped.2013.00053

[7] Warkany, J., Petering, H. G.: Congenital malformations of the central nervous system in rats produced by maternal zinc deficiency. Teratology, 1972, 5(3), 319-334.

[8] Tamura, T., Munger, R. G., Corcoran, C., et al.: Plasma zinc concentrations of mothers and the risk of nonsyndromic oral clefts in their children: a case-control study in the Philippines. Birth Defects Res. A Clin. Mol. Teratol., 2005, 73(9), 612-616.

[9] Eppley, B. L., van Aalst, J. A., Robey, A., et al.: The spectrum of orofacial clefting. Plast Reconstr. Surg., 2005, 115(7), 101e$114 \mathrm{e}$

[10] Eppley, B. L., Sadove, A. M.: Computer-generated patient models for reconstruction of cranial and facial deformities. J. Craniofac. Surg., 1998, 9(6), 548-556.

[11] Hohwii, L., Li, J., Olsen, J., et al.: Severe maternal stress exposure due to bereavement before, during and after pregnancy and risk of overweight and obesity in young adult men: a Danish National Cohort Study. PLoS One, 2014, 9(5), e97490. Doi 10.1371/journal.pone.0097490

[12] Abel, K. M., Heuvelman, H. P., Jörgensen, L., et al.: Severe bereavement stress during the prenatal and childhood periods and risk of psychosis in later life: population based cohort study. BMJ, 2014, 348, f7679

[13] Flint, P. W., Haughey, B. H., Lund, V. J., et al.: Cummings otolaryngology - Head and Neck Surgery. 3 -Volume Set, 5 th ed. Mosby Elsevier, 2015 .

[14] Yoon, P. W., Rasmussen, S. A., Lynberg, M. C., et al.: The nationa birth defects prevention study. Public Health Rep., 2001, 116(Suppl. 1), 32-40.

[15] Improved national prevalence estimates for 18 selected major birth defects - United States, 1999-2001. MMWR Weekly, 2006, 54(5152), 1301-1305. http://www.cdc.gov/mmwr/preview/ mmwrhtml/mm545la2.htm

[16] James, W. H.: Are oral clefts a consequence of maternal hormone imbalance? Evidence from the sex ratios of sibs of probands. Teratology, 2000, 62(5), 342-345.

[17] Marazita, M. L., Mooney, M. P.: Current concepts in the embryology and genetics of cleft lip and cleft palate. Clin. Plast. Surg., $2004,31(2), 125-140$.

[18] Sherwood, T. F., Mooney, M. P., Sciote, J. J., et al.: Cranial base growth and morphology in second-trimester normal human fetuses and fetuses with cleft lip. Cleft Palate Craniofac. J., 2001, $38(6), 587-596$.

[19] Merritt, L.: Part 1. Understanding the embryology and genetics of cleft lip and palate. Adv. Neonatal Care, 2005, 5(2), 64-71.

[20] Van Aalst, J. A., Kolappa, K. K., Sadove, M.: MOC-PSSM CME article: Nonsyndromic cleft palate. Plast. Reconstr. Surg., 2008, 121(1), Suppl. 1-14.

[21] Dudas, M., Li, W. Y., Kim, J., et al.: Palatal fusion - where do the midline cells go? A review on cleft palate, a major human birth defect. Acta Histochem., 2007, 109(1), 1-14.
[22] Dixon, M. J., Marazita, M. L., Beaty, T. H., et al.: Cleft lip and palate: understanding genetic and environmental influences. Nat. Rev. Genet., 2011, 12(3), 167-178.

[23] Shkoukani, M. A., Lawrence, L. A., Liebertz, D. J., et al.: Cleft palate: a clinical review. Birth Defects Res. C Embryo Today, 2014, 102(4), 333-342.

[24] Harville, E. W., Wilcox, A. J., Lie, R. T., et al.: Cleft lip and palate versus cleft lip only: are they distinct defects? Am. J. Epidemiol., $2005,162(5), 448-453$.

[25] Litle, V. R., Rice, T. W.: The esophagus: do sex and gender matter? Semin. Thorac. Cardiovasc. Surg., 2011, 23(2), 131-136.

[26] Mounoud, R. L., Klein, D., Weber, F.: A case of Goldenhar syndrome: acute vitamin A intoxication in the mother during pregnancy. J. Genet. Hum., 1975, 23(2), 135-154.

[27] Jugessur, A., Murray, J. C.: Orofacial clefting: recent insights into a complex trait. Curr. Opin. Genet. Dev., 2005, 15(3), 270-278.

[28] Huang, M. H., Lee, S. T., Rajendran, K.: Anatomic basis of cleft palate and velopharyngeal surgery: implications from a fresh cadaveric study. Plast. Reconstr. Surg., 1998, 101(3), 613-627.

[29] Gosain, A. K., Conley, S. F., Marks, S., et al.: Submucous cleft palate: diagnostic methods and outcomes of surgical treatment. Plast. Reconstr. Surg., 1996, 97(7), 1497-1509.

[30] Macisaac, Z. M., Rottgers, S. A., Davit, A. J. $3^{r d}$, et al.: Alveolar reconstruction in cleft patients: decreased morbidity and improved outcomes with supplemental demineralized bone matrix and cancellous allograft. Plast. Reconstr. Surg., 2012, 130(3), 625-632.

[31] Wilcox, A. J., Lie, R. T., Solvoll, K., et al.: Folic acid supplements and risk of facial clefts: national population based case-control study. BMJ, 2007, 334(7591), 464.

[32] Kelly, D., O'Dowd, T., Reulbach, U.: Use of folic acid supplements and risk of cleft lip and palate in infants: a populationbased cohort study. Br. J. Gen. Pract., 2012, 62(600), e466e472.

[33] Webby, G. L., Murray, J. C.: Folic acid and orofacial clefts: a review of the evidence. Oral. Dis., 2010, 16(1), 11-19.

[34] Dezsi, C., Magori, K. A., Szili, K.: The new and old methods of dental person and victim identification. [Fogászati személy- és áldozatazonosítás régi és új módszerei: irodalmi áttekintés.] Orv. Hetil., 2015, 156(19), 755-763. [Hungarian]

[35] Strong, E. B., Buckmiller, L. M.: Management of the cleft palate. Facial Plast. Surg. Clin. North Am., 2001, 9(1), 15-25.

[36] Seibert, R. W.: Lip adhesion in bilateral cleft lip. Arch. Otolaryngol. Head Neck. Surg., 1983, 109(7), 434-436.

[37] Yuzuriba, S., Mulliken, J. B.: Minor-form, microform, and minimicroform cleft lip: anatomical features, operative techniques, and revisions. Plast. Reconstr. Surg., 2008, 122(5), 1485-1493.

[38] Wilhelmsen, H. R., Musgrave, R. H.: Complications of cleft lip surgery. Cleft Palate, 1996, 3, 223-231.

[39] Campbell, A., Costello, B. J., Ruiz, R. L.: Cleft lip and palate surgery: an update of clinical outcomes for primary repair. Oral Maxillofac. Surg. Clin. North Am., 2010, 22(1), 43-58.

[40] Leow, A. M., Lo, L. J.: Palatoplasty: evolution and controversies. Chang Gung Med. J., 2008, 31(4), 335-345.

[41] Andersson, E. M., Sandvik, L., Semb, G., et al.: Palatal fistulas after primary repair of clefts of the secondary palate. Scand. J. Plast. Reconstr. Surg. Hand Surg., 2008, 42(6), 296-299.

(Szili Károly dr., Szeged, Somogyi u. 4., 6720 e-mail: szilikaroly@gmail.com) 